\title{
Author Index, Volume 75, 1999
}

Adamowicz, Wiktor L. - See Alavalapati, Janaki R.R.

Adamowicz, Wiktor L. - See Armstrong, Glen W. et al

111

Aguirre, Juan Antonio. - See Vlosky, Richard P. et al.

Alavalapati, Janaki R.R. and Wiktor L. Adamowicz. - Economic importance of forestry-related sectors in the provincial and northwestern regional economy of Alberta

Alavalapati, Janaki R.R., William White and Mike Patriquin. - Economic impacts of changes in the forestry sector: A case study of the Foothills Region in Alberta

Andison, David W. and Peter L. Marshall. - Simulating the impact of landscape-level biodiversity guidelines: A case study

Armstrong, Glen W., Steven G. Cumming and Wiktor L. Adamowicz. -

Timber supply implications of natural disturbance management

Arnott, J.T. - See Beese, W. J.

Avery, B. - See Volney, W.J.A. et al.

Baldwin, K.A. - See Cameron, D.A. et al.

Barnes, Trevor J., Roger Hayter and Elizabeth Hay. - "Too young to retire, too bloody old to work": Forest industry restructuring and community response in Port Alberni, British Columbia

Beaubien, J. - See Bernier, P.Y. et al.

Beaulieu, J. - See Messier, C. et al.

Beckley, Thomas M. - Forest community sustainability: Introduction to the theme

Beckley, Thomas M. and William Reimer. - Helping communities help themselves: Industry-community relations for sustainable timber-dependent communities

Beese, W.J. and T.J. Arnott. - Montane Alternative Silvicultural Systems (MASS): Establishing and managing a multidisciplinary, multi-partner research site

Béland, Martin, Yves Bergeron and Richard Zarnovican. - Natural regeneration of jack pine following harvesting and site preparation in the Clay Belt of northwestern Quebec

Bélanger, Louisé. - See Pominville, Pierre et al.

Bélanger, Louis. - See Potvin, François et al.

Bella, I.E. - See Cieszewski, C.J. et al.

Benoit, Robert. - See Ruel, Jean-Claude

Benton, R.A. and K.M. Pettersen. - Automated environmental monitoring and database management: Fantasies and realities

Bergeron, Yves. - See Béland, Martin et al.

Bergeron, Yves, Brian Harvey, Alain Leduc and Sylvie Gauthier. - Forest management guidelines based on natural disturbance dynamics: Stand and forest-level consideration

Bergeron, Yves, Brian Harvey, Alain Leduc et Sylvie Gauthier. - Stratégies d'aménagement forestier qui s'inspirent de la dynamique des perturbations naturelles : considérations à l'échelle du peulement et de la forêt

Bernier, P.Y., R.A. Fournier, C.H. Ung, G. Robitaille, G.R. Larocque, M.B. Lavigne, R. Boutin, F. Raulier, D. Paré, J. Beaubien and C. Delisle. Linking ecophysiology and forest productivity: An overview of the ECOLEAP project

Bernstein, Steven and Benjamin Cashore. - World trends and Canadian forest policy: Exploring the influence of consumers, environmental group activity, international trade rules and world forestry negotiations

Binkley, Clark S. and Susan B. Watts. - The status of and recent trends in forest sector research in British Columbia

Blevins, Leandra L. - See Prescott, Cindy E.

Bouthillier, Luc. - See Côté, Marc-André

Boutin, R. - See Bernier, P.Y. et al.

Brissette, John C., Robert M. Frank, Jr., Timothy L. Stone and Thomas A.

Skratt. - Precommercial thinning in a northern conifer stand: 18-year results

Brown, Paul M. - See Wellstead, Adam M. et al.

Burgess, D., S. Wetzel and F. Pinto. - Regenerating eastern white pine: A cooperative research approach

Burton, Philip J., Daniel D. Kneeshaw and K. David Coates. - Managing

forest harvesting to maintain old growth in boreal and sub-boreal forests

Cameron, D.A. - See Morrison, I.K et al.

Cameron, D.A., I.K. Morrison, K.A. Baldwin and D.P. Kreutzweiser. Black Sturgeon Boreal Mixedwood Research Project

Carolina, Edna. - See Vlosky, Richard P. et al.

Carpenter, Andrew M. and Winifred B. Kessler. - FORESTCARE:

Evaluating progress toward sustainable forest management in Alberta

Carrow, Rod. - Canada's Model Forest Program: Challenges for Phase II

Cashore, Benjamin - See Bernstein, Steven

Cayford, James H. - See Fedkiw, John

Chambers, Carol L., William C. McComb, John C. Tappeiner, Loren D.

Kellogg, Rebecca L. Johnson and G. Spycher. - CFIRP: What we

learned the first ten years

Charette, Lise. - See Jobidon, Robert et al.

Chemago, R. - See Volney, W.J.A. et al.

Chengaou, M. - See Messier, C. et al.

Chorney, M. - See Volney, W.J.A. et al.

Cieszewski, C.J., I.E. Bella and D. Walker. - An implementation of new

dynamic site index models in a company's timber supply analysis

Coady, Linda. - See Hackman, Arlin

Coates, K. David. - See Burton, Philip J. et al.
Colombo, S.J. and W.C. Parker. - Does Canadian forestry need physiology research?

Côté, Marc-André. - Possible impact of forest product certification on the

worldwide forest environment

Côté, Marc-André and Luc Bouthillier. - Analysis of the relationship among stakeholders affected by sustainable forest management and forest certification

Cumming, Steven G. - See Armstrong, Glen W. et al.

Delisle, Claude. - Treeshelters: A judicious choice for improving red

ash growth

Delisle, C. - See Bernier, P.Y. et al.

Delong, Deb. - See Smith, Jim

Déry, Stephane. - See Pominville, Pierre et al.

Duchesne, L.C. - See Staddon, W.J. et al.

Duckert, Dan R. - See Morris, Dave M.

D'Eon, Steve. - A retrospective look at 80 years of silvicultural research at

Petawawa

Edwards, I. - See MacIsaac, D.A. et al.

Emrich, Walter. - See MacLean, David A. et al.

Erdle, Thom A. - The conflict in managing New Brunswick's forests for timber and other values

Erdle, Thom A. and David A. MacLean. - Stand growth model calibration for use in forest pest impact assessment

Etheridge, Peter. - See MacLean, David A. et al.

Fedkiw, John and James H. Cayford. - Forest management: A dynamic evolving profession

Fleming, Richard A. - Statistical advantages in, and characteristics of, data from long-term research

Ford, E.D. - Using long-term investigations to develop silvicultura

theory for new forestry

Foster, N.W. - See Morrison, I.K. et al.

Fournier, R.A. - See Bernier, P.Y. et al.

Frank, Robert M., Jr. - See Brissette, John C. et al.

Gauthier, Sylvie. - See Bergeron, Yves et al.

Gladders, B. - See Volney, W.J.A. et al.

Graham, John. - Exploring the relationship between Aboriginal peoples

and the Canadian forest industry

Groot, A. - See Morisson, I.K. et al.

Hackman, Arlin and Linda Coady. - Linking forest protection and

certification: A step towards peace in the woods

Halseth, Greg and Jenny Lo. - New voices in the debate: The Quesnel

Women's Resource Centre and sustainable community development

Hammond, M.E.J. - See Volney, W.J.A. et al.

Harcksen, K.A. - See Ritchie, M.W.

Harvey, Brian. - See Bergeron, Yves et al.

Harvey, Brian. - The Lake Duparquet Research and Teaching Forest:

Building a foundation for ecosystem managemen

Hay, Elizabeth. - See Barnes, Trevor J. et al.

Hayter, Roger. - See Barnes, Trevor J. et al.

Helson, Blair V. - See Wanner, Kevin W. et al.

Higgins, Charlene. - Innovative forest practice agreements - What could

be done that would be truly innovative?

Hirsch, K.G. - See McAlpine, R.S. et al

Hoffman, T. - See Volney, W.J.A. et al.

Huang, Shonming, Stephen Titus, Daryl Price and Dave Morgan. -

Validation of ecoregion-based taper equations for white spruce in Alberta

Hubbes, M. - The American elm and Dutch elm disease

Jobidon, Robert, François Trottier et Lise Charette. - Dégagement

chimique ou manuel de plantations d'épinette noire? Étude de cas dans le

domaine de la sapinière à bouleau blanc au Québec

Johnson, Rebecca, L. - See Chambers, Carol L. et al.

Johnson, Chris J. - See Sherry, Erin E.

Johnson, J.D. - See Volney, W.J.A. et al.

Kakoyannis, Christina. - See Nadeau, Solange et al.

Kant, Shashi. - See Spinazze, Maria C

Kellogg, Loren D. - See Chambers, Carol L. et al.

Kessler, Winifred B. - See Carpenter, Andrew M.

Kimmins, J.P. (Hamish). - Biodiversity, Beauty and the "Beast": Are beautiful

forests sustainable, are sustainable forests beautiful, and is "small" always

ecologically desirable?

Kishchuk, B. - See Volney, W.J.A. et al.

Klenner, Walt and Alan Vyse. - Interdisciplinary research approaches

to address complex forest management issues

Kneewshaw, Daniel D. - See Burton, Philip J. et al.

Kneeshaw, Daniel D. - See Messier, Christine

Korber, D. - See Williamson, T. et al.

Krogman, Naomi T. - See Treseder, Leslie

Kostyk, Barry C. - See Wanner, Kevin W. et al.

Kreutzweiser, D.P. - See Cameron, D.A. et al.

Landals, Jean. - See Wysong, Mark

Langor, D.W. - See Volney, W.J.A. et al.

Larocque, G.R. - See Bernier, P.Y. et al

Lautenschlager, R.A. - Improving long-term silvicultural research for the

$21^{\text {st }}$ Century

Lautenschlager, R.A. - Intensive silviculture - Part of Ontario's new

"Living Legacy" 
Lautenschlager, R.A. and Cathy Nielsen. - Ontario's forest science efforts following the 1998 ice storm

Lavigne, M.B. - See Bernier, P.Y. et al.

Leblon, Brigitte. - Mapping forest clearcuts using radar digital imagary:

A review of the Canadian experience

Leduc, Alain. - See Bergeron, Yves et al.

Lee, C. - See Mitchell, A.K.

Lieffers, Victor J. - See Man, Rongzhou

Lin, Dolly. - See Zsuffa, Louis et al

Lo, Jenny. - See Halseth, Greg

Lowell, Kim. - see Potvin, François et al.

Luchkow, S. - See Volney, W.J.A. et al.

Luckert, Martin K. - Are community forests the key to sustainable forest management?

Lux, S. - See MacIsaac, D.A. et al.

MacFarlane, Derek. - See Wellstead, Adam M. et al.

MacIsaac, D.A., S. Lux, D. Sidders and I. Edwards. - Hotchkiss River

Mixedwood Timber Harvesting Study

MacIsaac, D.A. - See Volney, W.J.A. et al

MacLean, David A. - See Erdle, Thom A.

MacLean, David A., Peter Etheridge, Joe Pelham and Walter Emrich. -

Fundy Model Forest: Partners in sustainable forest management

Malcolm, D.C. - See Wilson, E.R. et al.

Mallett, K.I. - See Volney, W.J.A. et al

Man, Rongzhou and Victor J. Lieffers. - Are mixtures of aspen and white

spruce more productive than single species stands?

Man, Rongzhou and Victor J. Lieffers. - Effects of shelterwood and site

preparation on microclimate and establishment of white spruce seedlings in a

boreal mixedwood forest

Mar, Gary. - Welcome to the future

Marshall, Peter L. - See Andison, David W.

Maximchuk, M. - See Volney, W.J.A. et al.

Maynard, D.G. - See Volney, W.J.A. et al.

McAlpine, R.S. and K.G. Hirsch. - An overview of LEOPARDS: The Level of

Protection Analysis System

McComb, William C. - See Chambers, Carol L. et al.

McIver, H. Whitney. - See Wilson, E.R. et al.

Messier, Christine and Daniel D. Kneeshaw, - Thinking and acting differently

for sustainable management of the boreal forest

Messier, C., S. Parent, M. Chengaou and J. Beaulieu. - Juvenile growth and

crown morphological plasticity of eastern white pines (Pinus strobus L.) planted

along a natural light gradient: Results after six years

Mitchell, A.K. and C. Lee. - The Forest Ecosystem Research Network of Sites

(FERNS)

Mitchell, Al and Alan Vyse. - (Preface) Long-term Silvicultural Research Sites:

Promoting the Concept - Protecting the Investment 365

Mitchell, Alan. - See Thomson, Alan J.

Mohta, Dinesh and D.N. Roy. - Forests, fiber, and the environment - In view

of the fiber supply to the pulp and paper industry

Montes, Soihet. - See Vlosky, Richard P. et al.

Morgan, Dave. - See Huang, Shonming et al.

Morris, Dave M. and Dan R. Duckert. - Studying the impacts of harvest

intensity on site productivity of Ontario's black spruce ecosystems

Morrison, I.K., D.A. Cameron, N.W. Foster and A. Groot. - Forest research at the Turkey Lakes Watershed

Morrison, I.K. - See Cameron, D.A. et al.

Nadeau, Solange, Bruce Shindler and Christina Kakoyannis. - Forest

communities: New frameworks for assessing sustainability

Nielsen, Cathy. - See Lautenschlager, R.A.

Nordin, V.J., - Think strategy - think leadership - think vision

Oliver, Chadwick D. - The future of the forest management industry:

Highly mechanized plantations and reserves or a knowledge-intensive

integrated approach?

Opio, Christopher. - Forest management issues in a wildland-urban

interface: The case of West Bragg Creek Timber Licence in Alberta

Ozanne, Lucie K. - See Vlosky, Richard P. et al.

Paré, D. - See Bernier, P.Y. et al.

Parent, S. - See Messier, C. et al.

Parker, W.C. - See Colombo, S.J.

Parkins, John. - Contributions of sociology to forest management and policy development

Parkins, John. - Enhancing social indicators research in a forest-dependent community

Patriquin, Mike. - See Alavalapati, Janaki R.R. et al.

Payne, Peggy. - See Zsuffa, Louis et al.

Pelham, Joe. - See MacLean, David A. et al.

Pettersen, K.M. - See Benton, R.A.

Pinto, F. - See Burgess, D. et al

Pohl, G.R. - See Volney, W.J.A. et al.

Pominville, Pierre, Stephane Déry et Louisé Bélanger. - Dynamique de la

sapinière à bouleau jaune de l'est après une épidémie de tourdeuse des bourgeons de l'épinette

Potvin, François, Louis Bélanger et Kim Lowell. - Validité de la carte

forestière pour les habitats fauniques à l'échelle locale : une étude de cas en

Abitibi-Témiscamingue
Powers, Robert F. - If you build it, will they come? Survival skills for silvicultural studies

Prescott, Cindy E. and Leandra L. Blevins. - The Salal Cedar Hemlock Integrated Research Program (SCHIRP): Management through understanding Price, Daryl. - see Huang, Shonming et al.

Raulier, F. - See Bernier, P.Y. et al.

Reed, Maureen G. - "Jobs talk": Retreating from the social sustainability of forestry communities

Reimer, William. - See Beckley, Thomas M

Renke, Wayne. - See Woodard, Paul M.

Ritchie, M.W. and K.A. Harcksen. - Long-term interdisciplinary research

on the Goosenest Adaptive Management Area, Klamath National Forest,

California

Robitaille, G. - See Bernier, P.Y. et al

Rotherham, A.A. - Supply chain management and the forest industry

Rotherham, Tony. - An industrial perspective on strategic research needs

Roy, D.N. - See Mohta, Dinesh

Ruel, Jean-Claude et Robert Benoit. - Analyse du chablis du 7 novembre 1994 dans les régions de Charlevoix et de la Gaspésie, Québec, Canada

Samson, R. - See Williamson, T. et al.

Séguin, Armand. - Transgenic trees resistant to microbial pests

Sherry, Erin E. and Chris J. Johnson. - The forgotten forest: Revisiting the Forestland Allocation Strategy

Shindler, Bruce. - See Nadeau, Solange et al.

Sidders, D. - See MacIsaac, D.A. et al.

Silva, Gabriela. - See Vlosky, Richard P. et al.

Skratt, Thomas A. - See Brissette, John C. et al.

Smith, David. - The business of mergers

Smith, Jim and Deb Delong. - The West Arm Demonstration Forest - rising to the challenge

Spence, J.R. - See Volney, W.J.A. et al.

Spinazze, Maria C. and Shashi Kant. - Market potential for certified forest (wood) products in Ontario, Canada

Spycher, G. - See Chambers, Carol L. et al.

Staddon, W.J., L.C. Duchesne and J.T. Trevors. - The role of microbial

indicators of soil quality in ecological forest management

Stedman, Richard C. - Sense of place as an indicator of community sustainability

Stinson, Steven D. - 50 years of low thinning in second growth Douglas-fir

Stone, Timothy L. - See Brissette, John C. et al.

Tappeiner, John C. - See Chambers, Carol L. et al.

, Alan J. and AI Mitchell. - Collaborative knowledge managemen or long-term research sites

Titus, Stephen. - See Huang, Shonming et al.

Treseder, Leslie and Naomi T. Krogman. - Features of First Nation forest management institutions and implications for sustainability

Trevors, J.T. - See Staddon, W.J. et al.

Trottier, François. - See Jobidon, Robert et al.

Vlosky, Richard P., Juan Antonio Aguirre, Edna Carolina, Soihet Montes, Lucie K. Ozanne and Gabriela Silva. - Certification in Honduras: Perspectives of wood product manufacturers, consumers, NGOs and government forest policymakers

Volney, W.J.A., H.E.J. Hammond, D.G. Maynard, D.A. MacIsaac, K.I. Mallett D.W. Langor, J.D. Johnson, G.R. Pohl, B. Kishchuk, B. Gladders, B. Avery, R. Chemago, T. Hoffman, M. Chorney, S. Luchkow, M. Maximchuk and J.R. Spence. - A silvicultural experiment to mitigate pest damage

Vyse, Alan. - See Klenner, Walt

Vyse, Alan. - See Mitchell

Vyse, Alan. - Is everything all right up there? A long-term interdisciplinary silvicultural systems project in a high elevation fir-spruce forest at Sicamous Creek, B.C.

Walker, D. - See Cieszewski, C.J. et al. Wanner, Kevin W., Barry C. Kostyk and Blair V. Helson. - Recommendation for control of cone and seed insect pests of black spruce, Pices mariana (Mill.) B.S.P., with insecticides

Watts, Susan B. - See Binkley, Clark S.

Webster, Henry H. - Some sources of persistent error in thinking about resources

Wellstead, Adam M., M. Paul Brown and Derek MacFarlane. - Exploring woodlot owner managing and marketing decisions: Implications for Nova Scotia forest policy

Wetzel, S. - See Burgess, D. et al.

White, William. - See Alavalapati, Janaki R.R. et al.

Williamson, T., R. Samson and D. Korber. - Economic performance of forest-reliant census subdivisions between 1981 and 1991

Wilson, E.R., H. Whitney McIver and D.C. Malcolm. - Transformation to irregular structure of an upland conifer forest

Woodard, Paul M. and Wayne Renke. - Assigning liability to railways without evidence

Wysong, Mark and Jean Landals. - New software allows Weyerhaeuser to master chemical safety compliance

Zarnovican, Richard. - See Béland, Martin et al.

Zsuffa, Louis, Dolly Lin and Peggy Payne. - One-way crossing barriers in some interspecific crossed of Aigeiros and Tacamahaca poplars 